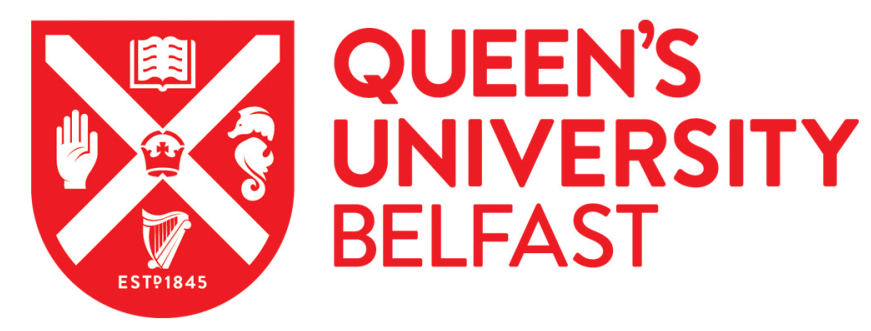

\title{
Regulating for mutual gains? Non-union employee representation and the Information and Consultation Directive
}

Cullinane, N., Donaghey, J., Dundon, T., Hickland, E., \& Dobbins, T. (2014). Regulating for mutual gains? Nonunion employee representation and the Information and Consultation Directive. International Journal of Human Resource Management, 25(6), 810-828. https://doi.org/10.1080/09585192.2013.770781

Published in:

International Journal of Human Resource Management

Document Version:

Peer reviewed version

Queen's University Belfast - Research Portal:

Link to publication record in Queen's University Belfast Research Portal

Publisher rights

(c) 2013 Taylor \& Francis.

This is an Accepted Manuscript of an article published by Taylor \& Francis in International Journal of Human Resource Management on 14 Mar 2013, available online: http://www.tandfonline.com/[Article DOI]

\section{General rights}

Copyright for the publications made accessible via the Queen's University Belfast Research Portal is retained by the author(s) and / or other copyright owners and it is a condition of accessing these publications that users recognise and abide by the legal requirements associated with these rights.

Take down policy

The Research Portal is Queen's institutional repository that provides access to Queen's research output. Every effort has been made to ensure that content in the Research Portal does not infringe any person's rights, or applicable UK laws. If you discover content in the Research Portal that you believe breaches copyright or violates any law, please contact openaccess@qub.ac.uk. 
Regulating for Mutual Gains? Non-Union Employee Representation and the Information \& Consultation Directive

Niall Cullinane*, Jimmy Donaghey**, Tony Dundon***, Eugene Hickland*** and Tony Dobbins ${ }^{* * * *}$

*Queen's University Management School, Queen's University, Belfast

** Warwick Business School, University of Warwick

${ }^{\star * \star}$ J.E. Cairnes School of Business and Economics, National University of Ireland Galway

${ }^{\star * \star \star B a n g o r ~ B u s i n e s s ~ S c h o o l, ~ B a n g o r ~ U n i v e r s i t y ~}$ 


\title{
Regulating for Mutual Gains? Non-Union Employee Representation and the
}

\section{I\&C Directive}

\begin{abstract}
Interest in 'mutual gains' has been principally confined to studies of the unionised sector. Yet there is no reason why this conceptual dynamic cannot be extended to the non-unionised realm, specifically in relation to non-union employee representation (NER). Although extant research views NERs as unfertile terrain for mutual gains, the paper examines if NERs developed in response to the European Directive on Information and Consultation of Employees may offer a potentially more fruitful route. The paper examines this possibility by considering three cases of NERs established under the I\&C Directive in Ireland, assessing the extent to which mutual gains were achieved.
\end{abstract}

Key Words: mutual gains, non-union employee representation, Information and Consultation Directive. 


\section{Regulating for Mutual Gains? Non-Union Employee Representation and the Information and Consultation Regulations}

\section{Introduction}

Interest in the 'mutual gains enterprise' has been a feature of employment relations studies since the publication of Kochan and Osterman's (1994) text on the subject.The concept outlines that while management and workers interests may diverge, there is ample opportunity, through problem-solving arrangements, to create shared benefits for both parties. Interest in mutual gains has since blossomed, although the literature has been largely confined to unionised settings. Such inclinations are surprising given the decline in unionisation and the growth in multiple non-union voice regimes (Lewin, 2010). Furthermore, as Walton and McKersie (1965) note, problem-solving activity can be realised through a variety of mechanisms. Given that problem-solving is claimed to be an inherent feature of mutual gains, then there is no reason why its study cannot be extended to non-union relations. As Ackers et al. (2004:16) argue: "It seems unreasonable and sociologically unproductive to rule out non-union forms, whether voluntary or stateregulated....before examining the evidence".

Parallel to studies in mutual gains has been a progressive interest in the dynamics of non-union employee representation (NERs). Initially a focus of American employment relations, interest in NERs rapidly took on international dimensions, particularly in other liberal-market countries. NERs often find their genesis around management seeking to solve workplace issues by establishing a representation forum. According to Kaufman and Taras (2000) and Gollan (2010), resolving grievances and problems lie at the centre of NER evolution. In the absence of 
unions, NERs may, theoretically, offer scope for the realisation of some mutual gains type outcomes (Johnstone et al. 2010). Yet the analysis has been mixed. Dietz et al. (2005) posit potential gains from NERs, whilst Knell (1999) finds marginal differences in effect between non-union and union partnership style arrangements. Johnstone et al. (2010) suggest that if the benchmarks for measuring the success of NER partnerships are more modest, and if weighting is given to process rather than outcome, then such arrangements can benefit both employer and employee. Yet these are isolated islets of optimism in a more general sea of scepticism: a range of authors see NERs as ineffective, managerially dominated creatures (Badigannaver and Kelly, 2005; Gollan, 2007; Upchurch et al. 2008).

Significantly, the environment within which evidence about NERs is collated, in the UK and Ireland in particular, has institutionally changed in light of the transposition of the European Directive 2002/14/EC, more commonly known as the Information and Consultation Directive $(\mathrm{I \& C})$. These regulations established, for the first time in the UK and Ireland, a framework giving employees the right to be informed and consulted by their employers, including the potential for NER and other non-union mechanisms. It is not inconceivable that some firms will re-consider their voice regimes in response to the regulations. In this paper, a sample of NER regimes, established in Northern Ireland and the Republic of Ireland in light of the I\&C regulations, are examined to consider whether such arrangements offer favourable opportunities for mutual gains realisation. Given the European regulatory context noted above, NERs, in some cases, may not be wholly managerially-sponsored to the degree that they reflect legislative requirements and, theoretically, provide employees with the opportunity of representative voice buttressed by statutory 
supports. Furthermore, the concept of mutual gains has been undeveloped in the NER literature as most research has opted to consider comparisons with union voice or the possible impact on high performance working (Kim and Kim, 2004). This article therefore addresses the question: 'Do mutual gains result from NERs created in response to the I\&C Directive?' The paper is structured as follows: Section 2 and 3 review existing literature on mutual gains, NERs and the I\&C regulations. The research methodology is outlined in Section 4 and the findings from three cases of firms, with I\&C influenced NER regimes, are presented in Sections 5 and 6. The paper concludes with a discussion of the findings in Section 7.

\section{Mutual gains reviewed}

The notion of mutual gains is anchored on a premise that whilst management and workers interests may diverge, there is ample opportunity to create jointly shared benefits. Although no exact definition of mutual gains exists, it might be interpreted as follows:

[1] Management and workers are conscious of the shared consequences of their actions and therefore openly exchange information in a cooperative fashion so as to highlight areas of joint interest.

[2] They then generate decision making options, through problem-solving structures, and

[3] Choose those options that offer the highest joint returns for the parties.

(c.f. Kochan and Osterman, 1994; McKersie et al. 2008) 
The literature is not entirely prescriptive as to what procedural and/or substantive features of employment are assigned to mutual gains territory, though it is generally thought to incorporate diverse aspects like pay, employment security, training, job redesign, participative or involvement structures. Much of the mutual gains literature has focused on the concept of firm-level 'partnership' (Danford et al. 2004; Johnstone et al. 2010). Under the perception that collective bargaining is being marginalised in the 'new economy', mutual-gains partnerships, based upon shared understandings between employers and employees, have been championed by advocates to ensure collective dynamics remained relevant to 'high performance workplaces'. It also served as a rebuff to neo-classical economics, wherein the union presence was viewed as a source of 'rigidity' (Metcalf, 1989). Building on Freeman and Medoff (1984), Kochan and Osterman argued that rather than being blockages to productivity improvements, worker representatives, in collaboration with management, and underpinned with institutional supports, could engage in joint problem solving to improve both firm performance and returns for workers. Management and workers are still held to maintain their own separate interests, but ultimately seek to satisfy such contiguous interests through co-operation (Kochan, 2008). Shared understandings are said to arise from such coalitions about the challenges facing the firm and lead to the interests of employees being actively considered in business strategy. What is important in such considerations is 'how' problem-solving is played-out in practice. Bacon and Blyton (2007:831) show that the processrequires a degree of conflictual behaviours for mutual gains outcomes to be regarded as genuine for both sides; for example, a trade-off between wage increases for workers with productivity savings for management through staffing 
reductions. In other words, mutual gains require some requisite degree of distributive power.

Empirically, there are a variety of results which appear to support all three strands. Whilst studies suggest that mutual gains outcomes are viable (Guest et al. 2008), others have evidenced more negative conclusions (Kelly, 2004). There is evidence that mutual gains approaches trigger employee access to areas of decision-making previously the preserve of management (Dobbins and Gunnigle, 2009). Yet there is also evidence that mutual gains can be confined to operational and trivial matters (Teague and Hann, 2010). These latter outcomes can often be underpinned by weak management commitment. More broadly, Stuart and Martinez-Lucio (2005) argue that for partnership to be effective, it requires support by institutions which deliver long-term mutual gains.

\section{Mutual gains and non-union employee representation}

The study of mutual gains has been largely developed and examined in the unionised sector. But as Lewin (2010) and Johnstone et al. (2010) have argued, there seems to be no particular reason to rule out the possibility of mutual gains arrangements in the non-union sector. Indeed Stuart and Martinez-Lucio (2005) have identified the need for further research of this arrangement. In this context, it is useful to turn our attention to alternative means developed within the non-union sector for employee representation. Non-union employee representation (NER) is one such mechanism. NERs are characterised as involving only employees in the organisation as members of the representative body; there is no formal linkage to trade unions; the resources are supplied by the organisation in which the body is based; and it 
involves representation of employee function rather than direct forms of participation (Gollan, 2010).

However, scholars for the most part tend to treat managerially-sponsored NERs sceptically. As Butler (2005) notes, NERs have deficiencies in both 'power' and 'autonomy'. By power, it is operationalised to mean 'manifest power' in terms of the 'scope' and 'range' of issues influenced or controlled by the employee representatives. With reference to 'scope', this may be conceived as a scale of possible involvement extending from information provision at one end to negotiation at the other, with consultation claiming an intermediary position. 'Range' on the other hand suggests breadth of issues falling between 'tea and toilet roll' type issue at one end, to areas typically the preserve of managerial prerogative at the other; investment, job security and work organisation. NERs appear skewed towards information provision however, with employee influence being minimal and issues confined to the relatively marginal (Badigannavar and Kelly, 2005, Upchurch et al. 2008). Autonomy, taken to mean 'self-rule' and freedom from external control (Butler, 2005: 276), can be defined operationally as the extent to which representative structures are independent of managerial diktat and the degree to which terms of reference, constitution, agenda and process are determined by employees or their representatives. This may address the extent to which representatives are subject to "explicit and/or implicit pressures that function as signposts curbing and/or sanctioning specific modes of behaviour" (Butler, 2005: 277). Again the literature tends to be sceptical of NERs freedom from managerial constraints and manipulation. Left to their own devices, employers introduce weak forms of voice that have little or no independence from management. Employee representatives in 
such structures, with no independent organisational supports and often with limited access to training and resources, may be easily manipulated.

Prima facie then, there are reasons to be sceptical about the efficacy of NERs to deliver mutual gains. Unlike the dynamic in the unionised sector, employees are unlikely to have independent, distributary power resources and sanctions to fall back upon. Such pre-emptory, background resources may be necessary to impel mutual gains type behaviour to work successfully. However, it is important to examine if these elements of deficient power and negligible autonomy, that dominate research on NERs, can be moderated by recent regulatory developments. Specifically, we refer here to the national implementation of the Information and Consultation Directive (I\&C) in the UK through the Information and Consultation of Employees Regulations 2004 and in Ireland through the Employees (Provision of Information and Consultation) Act $2006^{1}$. Formally, the Directive's implementation is of importance for the voluntarist regimes of the UK and Ireland where statutory voice regulation is weakly embedded. These provisions offer what Hall (2005) describes as a 'legislatively-prompted voluntarism' for worker information and consultation: emphasis is placed on workers and management reaching a voluntary agreement, with standard legal provisions offering a "fallback" (providing for election of employee representatives on collective forums with accompanying rights to information and consultation) where there is a failure to agree. The legislation is equally applicable in the non-union sector as it is in the unionised. Moreover, these rights are underpinned by EU social policy objectives to stimulate a culture of mutual gains through "strengthening social dialogue with a view to promoting change compatible with

\footnotetext{
${ }^{1}$ While there are a number of technical differences between the UK and Irish implementations, they are beyond the scope of this article.
} 
preserving the priority objective of employment" (Directive 2002/14/EC: 29). Prior to transposition, some scholars foresaw the regulations as holding far reaching consequences for the way British and Irish employers informed and consulted employees over a wide range of workplace issues (Sisson, 2002).

Yet the uptake of legally enacted rights to date does not appear transformative of the I\&C terrain in the UK and Ireland (Dundon et al., 2006; Hall et al., 2011). However, some firms may have been influenced by the Directive to, either review arrangements as a result of the regulations, or, initiate new arrangements (Wilkinson and Gollan, 2007; Koukiadaki, 2010). This adds a nuance to appreciating NER potential for mutual gains as such arrangements are now supported by legislation and are, in theory, provided with some formal institutional distance from management. Thus, in keeping with the above theoretical benchmarks, an element of increased power and autonomy is afforded to those NERs legislatively backed by the transposed Directive. In firms with 50 or more employees, I\&C forums are formally no longer wholly managerially sponsored, but theoretically, have recourse to independent statutory backing where workers seek to pursue it. In terms of 'power', the UK and Irish legal instruments theoretically enable greater 'scope' and 'range' over issues influenced. Employees are provided with the right to information and consultation about issues impacting on employment, work organisation or contractual relationships. Thus the scope is fixed at the intermediate level of consultation with the range of issues impacting on more high-level substantive and procedural aspects of employment. 
The regulatory frameworks specify that information must be given in such ways as to enable representatives to conduct an adequate study and prepare for consultation. Where in place, employers are obliged to give employee representatives an opportunity to meet with them and give their opinion on matters subject to consultation. But the regulations in the UK and Ireland have been viewed as a minimalist transpositional interpretation of the EU Directive and the constraints compelling employers to implement collective employee representative rights are quite a blunt instrument: it is highly significant that such rights are not automatic and must be triggered by employees. Employers may utilise direct arrangements (in Ireland) and 'pre-existing agreements', which can further dilute the regulations' potential; although the regulations state that these must be approved by employees, set out information and consultation provisions and be capable of independent verification. Thus as Wilkinson and Gollan (2007: 1138) argue, "the I\&C regulations could easily result in 'weak' employer-dominated partnerships and non-union firms using direct communications and information while marginalizing collective consultation". Referring back to power, what appears crucial here are latent "power bases' or 'resource possession' as allied to a subjective element or a "willingness to act" (Butler, 2005: 276). Poole (1975: 17) defines latent power as reflecting the power bases or resources at the disposal of particular parties; this is seen as an underlying power of particular groups and their potential for achieving given ends. The extent to which employees can exercise power over the scope and range of I\&C issues in NERs depends on their awareness of, and willingness to, take the opportunities afforded in the regulations: for example to secure negotiated agreements, trigger the 'standard rules' or to draw on supports of overseeing state inspectorates or the civil courts to ensure compliance (or issue penalties). Employee 
capacity to enact such potentialities might be speculated to be weak of course: one survey of a sample of British employees found that only 13 per cent were aware of the regulations (CHA, 2005 cited in Wilkinson and Gollan, 2007).

With reference to the other measurement benchmark of 'autonomy', the regulations offer opportunities that assist independence from managerial manipulation. Whether direct involvement, pre-existing or negotiated agreements or standard rules apply [1], the arrangements must be approved by either employees and/or their representatives and be capable of independent verification. Where rights are triggered by employees, employers are obliged to either engage in a 'negotiated agreement' or the 'standard rules' with independently elected or nominated employee representatives. Thus the terms of reference, constitution and overall representative framework are theoretically independent of managerial control or manipulation. Some measure of autonomy has been embedded into the legislation, albeit minimalist, for employee representatives to act independently of management through rights to paid-time off to prepare and attend meetings; rights to facilities for information and consultation duties and rights to paid time off for training courses relevant to I\&C duties; as well as protection from unfair dismissal. All employees must be entitled to take part in the appointment or election of representation and this process must be arranged in such a way that all employees are represented. However it is worth noting that there may well be gradations of autonomy in this regard: it is not implausible that structures 'triggered' by employees might offer greater room for autonomy than managerially crafted pre-existing agreements (even though the latter mechanism still requires adherence to regulatory stipulation and 
employee consent). This implies a certain element of context dependency in unpacking the efficacy of the regulations.

Whilst the opportunities of greater power and autonomy are therefore present under the regulations, our analysis hitherto suggests a reliance on employees to ensure such statutory supports are mobilised. Yet it is not inconceivable that where employers adhere to a sophisticated non-union style, there may be a greater willingness on their part to utilise the legislative supports to ensure meaningful NER arrangements. Given the potentialities of greater power and autonomy offered by the regulations, the question becomes to what extent it is conducive to fostering mutual gains. Initial research on I\&C regulations would suggest mixed outcomes: for example, Taylor et al. (2009) dismiss its capacity for example to influence redundancy outcomes in the context of six UK unionised case studies. Alternatively, the assessment by Hall et al. (2011), based on a more empirically encompassing sample and set of issues, is more tempered, suggesting that while the legal framework remains at the periphery, outcomes can be vary by degrees of management commitment. Koukiadaki (2010) similarly uncovers mixed results in this regard; with some success in an online, non-union commercial bank but largely symbolic forms in a business and management consultancy. Notably, she argues that "much work remains to be done on the ways in which such information and consultation arrangements can evolve as effective mechanisms for the exercise of the 'voice' rights that the Directive confers" (Koukiadaki, 2010: 366). Hence, this paper focuses on employee voice in non-union enterprises and addresses the question, 'Do mutual gains result from NERs created in response to the I\&C Directive?' 


\section{Research Methodology}

The data presented in this article is derived from a larger project investigating the impact of the I\&C regulations in the Republic of Ireland and Northern Ireland. In this project, a multiple case study design was adopted to obtain evidence from different economic sectors of activity, for between and within sector comparisons and across the different jurisdictions. Given this paper's select concerns, the cases presented here represent a smaller sub-set of firms and is offered for purely illustrative purposes. Three cases aligned with the theoretical interest in NERs shaped by the regulations. Data collection in the three cases was predominately qualitative-based involving interviews with key management and employee respondents. Interviewees involved a minimum of senior HRM, senior manager, line manager, employee representative and six employees. Secondary methods consisted of internal and external documentary material. The research involved multiple visits to the company sites over a two year period.

Insert Table 1 Here

The first case is BritCo, a former UK state-owned enterprise in the services field and now the second largest firm in its sector in Ireland [1]. In 2005, BritCo in the Republic merged with the pre-existing Northern Ireland group, forming BritCo Ireland. At the time of research, it employed 3000 staff in Ireland (2000 in the Republic and 1000 Northern Ireland). While the business operates on an all-island basis, the company's human resource approach is different across the two jurisdictions: in Northern 
Ireland, there is a history of unionised arrangements; in the Republic, which is nonunion, a voice regime was created in response to the Regulations (the latter the focus for this paper). Interviewees were comprised of six managers, one union organiser, four non-union representatives, and thirteen employees from various operational levels of the company.

The second case is ManufactureCo: a family-owned company based in Northern Ireland. It manufactures window blinds for the domestic market. The company underwent considerable expansion during the early years of the millennium, expanding from approximately 50 to 200 employees in five years and, at the time of the research, employed 300 employees at its single-site facility. A non-union company, the firm set up the 'Employee Forum' in 2006 under the influence of the I\&C Directive. The data for the case is based on qualitative data derived from the Chief Executive, two members of the HRM team, four employee representatives and 10 employees.

The third case is RetailCo: a British retail company with 19 stores across Ireland with 1,500 employees at the time of research. The company is non-union with a paternalistic management philosophy. Voice mechanisms involved an integrated NER at all corporate levels. Whilst the NER pre-dates the regulations, RetailCo redesigned elements of the NER to adhere with legislative requirements. Interviews were conducted with HRM Director for the Republic, the HR Director for Northern Ireland, 10 managerial grades at store level, six employee representatives and six employees. 
The data from the three cases is presented thematically. The findings consider first the regulations' influence on the establishment, or redesign, of the NERs. The process and outcomes of NER are then considered; particularly whether the formal properties of power and autonomy offered by the regulatory influenced arrangements were enabling of mutual gains.

\section{The I\&C Directive, NER Creation and Structure}

BritCo, on entering the Republic of Ireland market in 2000, acquired a non-union firm employing close to 2,000 employees. This latter company had been an entrepreneurial-owned, non-union firm. In turn however, this meant a vacuum in relation to collective employee voice. With the imminent transposition of the Directive in the Republic in 2005, management sought to fill this vacuum with an 'Information and Consultation Forum' that would meet the Directive's requirements. This was designed to be a 'pre-existing agreement' but framed against the standard provisions of the Directive. This agreement appears to have been 'approved by employees' in a manner consistent with Section $9(3 a)$ of the relevant Irish Act. That is, the arrangement was held to be approved by employees "where the result of employing any other procedure agreed to by the parties for determining whether the agreement has been so approved discloses that it has been so approved". In practice, this seems to have amounted to little else in BritCo than senior managers handpicking 'representatives' to sign off on the arrangement. In interviews in 2009, senior management noted that the forum was essentially a 'tick the box exercise' in order to be seen to comply with the regulatory requirements. Whilst formal provisions for elected employee representatives were provided for, their actual selection wasinformal and haphazard in practice, with some employees simply asked by their 
line manager to attend forum meetings. Meetings of the forum were similarly disorganised and irregular, with no set agenda. In most cases, they were simply a report by senior management on the financial situation with discussion kept to a minimum. In any case, the forum was largely defunct by the middle of 2006 as no meetings were held subsequently. Indeed employees interviewed in 2009 had not even heard of the 'Information and Consultation Forum'.

From early 2007, unrest amongst employees in BritCo in the Republic was evident regarding aspects of a then ongoing corporate restructuring. A number of organisational departments were closed down and moved to Northern Ireland with a number of employees expected to relocate. There were also fears around potential redundancies as a consequence of the restructuring, an issue further aggravated by employee concerns over the apparently low terms and conditions on offer as evident in the staff handbook. Added to this were grievances over salary structure and scales, namely a lack of transparency over employees' salary grading. This led to a union organising campaign in early to mid-2007. Support for the union appears to have been strong with claims by the union that $30 \%$ of BritCo employees became members between 2006 and 2008. Management interpreted union support as requiring changes in voice relations resulting in the inoperative 'Information and Consultation Forum' being, as one union organiser wryly put it, "taken down from a dusty shelf" and re-calibrated by management. The forum was re-branded BritCo Vocal in the summer of 2007 and was utilised far more vigorously, meeting every four weeks instead of at the end of every three months. According to the HRM Director of BritCo: 
The information and consultation forum was in place before we received advances from the union, but when we rebranded to Vocal there was certainly a little bit more noise in the system. So we enhanced the relationship, because if we got that right, we felt employees wouldn't see the need for a third-party.

In ManufactureCo, the NER was initially prompted by other influences, chiefly stemming from management seeking accreditation from Investors In People (IiP). For most of its history, the company was a family managed entity with a paternalistic informality characterising employment relations. Despite having grown in organisational capacity and numbers employed, as well as professionalising internal management structures in the latter half of the last decade, ManufactureCo had no system of formal voice apart from individual grievance and disciplinary procedures. The liP Group advised that implementing a formal information and consultation structure would assist in the accreditation process and suggested that the Northern Ireland Labour Relations Agency (LRA) might assist management in best-practice on the matter. An LRA advisor was brought into ManufactureCo to assist the company in designing its NER and he based the constitution and structure on the standard provisions of the Regulations. Employee approval for the Forum was secured through a company-wide ballot, with a 60 per cent participation rate amongst employees and full endorsement of the NER arrangement.

Whilst the forum was set up in 2005, by the time of research in 2009 and 2010, the HRM Team noted that, in its first years, the NER had played a negligible role in company affairs. The HRM manager commented that by the time of his appointment 
in 2007, the forum was limited to health and safety considerations. Similar to BritCo, the NER was reinvigorated as a result of what the Chief Executive described as an "aggressive" union recognition campaign at the plant. Unlike BritCo however, support for the union was at a low level: despite lodging an application for statutory union recognition under the UK union recognition provisions, the union did not satisfy the Central Arbitration Committee (CAC) that 10 per cent of workers in the company were union members or that that a majority of workers at the plant favoured recognition. Despite this, management were conscious that an underlying reservoir of grievances may have existed and this encouraged the promotion of the NER. Of note, is that despite the apparently low level of support for the union at the plant, the researchers had to enter into agreement with management that no issues pertaining to trade unionism would be raised in the data collection instruments and that questions of trade union representation would not be broached with any employees. Yet none of the employee representatives or employees interviewed raised issues around trade unionism of their own accord, while the HRM team were of the opinion that there was no union activity in the plant at the time of the research.

The final case, RetailCo, had a long history of internal voice arrangements, a policy shaped by the company's non-union paternalism. Traditionally a store level consultative committee was used in company sites, with the possibility of pursuing issues to a divisional office level. This was largely an ad-hoc affair and could often be dependent upon local-level managers' commitment. In the late 1990s, this practice was restructured, with a new multi-tiered NER introduced to give more scope and depth to consultative arrangements. This structure was known internally as Bottom-Up. It operated through a sequence of meetings at store, regional, 
divisional and national level, organised in a uniform manner throughout the company. Meetings were structured to take place at each level on a quarterly basis, starting at store level, followed by meetings at progressively higher levels so that, where deemed necessary, problems could be progressed from store to national level. Following a review of the system in 2001, Bottom-Up was re-fashioned to preempt the introduction of the I\&C regulations. This provided a formal nomination and election procedure, by secret ballot, for store level employee representatives as well as consultative roles in respect of work organisation, employment and contractual relationships. Prior to this, there had been no consistent approach with employee representative selection: either enthusiastic volunteers or ad-hoc selection by line management. In addition, formal allowances for training were introduced for representatives as well as an agreed allocation of time to carry out duties. According to management the change was claimed to be driven by a desire to deepen employee participation generally as much as a desire to meet the regulations. Yet there was also evidence that the forum served the needs of union avoidance:

With the Forum, it was never explicit, but the company is not a unionised company...The Forum is a way of saying that we operate the type of culture that we would never want people to think they'd need a union. That they had enough avenues for grievance procedures or Forum procedures to be able to deal with any situations in the store.

HRM Director, Republic of Ireland

\section{NERs, Power, Autonomy, Problem-Solving and Mutual Gains}

Mutual gains rotates on an assumption that, in the process of problem-solving, both sides exchange information to advance interests that are deemed beneficial to both parties, with the subsequent generation of options and final, the choosing of those that offer the highest joint returns. The extent to which these dynamics were evidenced in the I\&C influenced NERs is now considered. 
At BritCo there is partial evidence of mutual gains in the reconfigured NER; albeit a constrained form of mutuality that distributed limited independent power and autonomy to employee representatives vis-à-vis management. One of the first matters raised by employee representatives was the widespread concern over potential redundancy payment on offer, a fear, noted above, to be exacerbated by the context of corporate restructuring. This was a core issue behind the union organising campaign. Redundancy terms relied on statutory entitlements alone, considerably lower than redundancy terms available to BritCo employees in Northern Ireland. Through the NER, management explained that the terms presented in the company handbook had simply been replicated from the original Irish company prior to the takeover. Terms were low in the original handbook, management advanced, because as a young company, staff would not have held long service. Management conceded that review and formalisation of redundancy terms would be undertaken to ensure they matched industry standard. It was suggested by employee representatives that efforts be made to re-write the handbook in consultation with employees. Employee representatives also sought, and gained, a month to review the final handbook, and the terms contained therein, through holding meetings with their constituencies on any pertinent concerns. A series of NER meetings were then dedicated to discussing issues aired by representatives' constituents. An outcome from this process was that aspects of the Northern Irish redundancy arrangements were introduced into the Republic: the practice of a redundancy pool wherein employees at risk of losing their jobs were given eight weeks to secure a new position or project inside BritCo Ireland. In sum, an area of concern to both parties, albeit for different reasons, was addressed through openly exchanging information, 
allowing feedback and influence from employee representatives' constituents through the assigned structures. This constituted an issue of mutual gains problem solving for management insofar as it enabled them to dissipate a contentious issue behind the union organising and resolve an issue of employee dissatisfaction. For employees', articulating concerns over redundancy and being afforded a consultative role, enabled changes that improved redundancy terms.

However distributive tensions moderated the extent of mutuality, which still largely took place on management's terms; management refused to extend the 'no compulsory redundancy' policy used in Northern Ireland. Despite this, employee representatives, and employees interviewed, were not overly dissatisfied with the resolution process. The power imbalance was further evident when employee representatives sought solution to the second core concern underpinning the union organising drive: failure to disclose internal salary scales. Through Vocal, management expressed their unwillingness to a change of practice on this matter, claiming that open disclosure of such information might be passed to competitors. Whilst representatives pressed for disclosure of salary pay bands, management in response offered to post a confidential sheet to individual employees, outlining their particular roll code, job family and benchmarked pay range. The proposed solution appeared to be unsatisfactory to staff who regarded secrecy on the matter to be, as one employee representative put it, "very much cloak and dagger" and lacking transparency.

Furthermore, as illustrated in Table 2, the scope and range of NER voice tended to narrow over time. Evidence suggests that once management redressed underlying 
problems prompting union organising, the breadth of issues addressed at Vocal narrowed. Attempts at raising other substantive issues, such as the conduct of performance appraisals by line management, were claimed by representatives to be written off the agenda or 'glossed over' by management.

\section{Insert Table 2 here}

At best, employees maintained a degree of influence over somewhat more trivial decisions. For example, on the re-carpeting of office space, employee representatives were given access to departmental budgets and empowered to come up with re-furbishing solutions. Similar processes have been at work in the selection of private health care insurers for employees. In this context of a narrowing of the mutual gains arena, three representatives resigned from the forum under the perception that it was "toothless" on more substantive issues. It is noteworthy that two of these representatives were active union members and had been elected by employees to act as NER representatives. It is instructive to note that the union message to members, and potential recruits, in leaflets and press statements was that Vocal represented little more than "a tried and tested union avoidance formula". The NER was regarded by the union as a separate "communications body" and not comparable to the sought after collective bargaining arrangement.

It was notable that ManufactureCo management described their NER as a communicative rather than a consultation forum. For the most part, mutual gains amounted to management acting on grievances rather than the parties generating decision-making solutions through the problem-solving dynamic described above. 
For example, employee representatives at the forum raised concerns over the bonus for efficiency and productivity. The crux of the grievance was the existence of a bonus for 'productivity', but none for 'quality'. Further, the bonus system was teambased, with one outcome being that poor individual performers could drag an overall team down, eroding the payout. Management reviewed existing procedures and an amalgamated efficiency and quality bonus system was subsequently introduced, although no change was made to the team structure. Employees had no input into devising the new bonus scheme, apart from raising it as a grievance at the NER. Indeed, this same scheme was five months later unilaterally frozen by management in light of economic uncertainty. In short, NER at ManufactureCo appeared based on preserving managements' right to manage, with some limited concessions on communicative interaction based around grievance resolution. It did not appear to be the representative joint problem-solving dialogue geared towards mutuality, as aspired to in the I\&C Directive.

That the NER was a lubricant for communicating is evident from how information around the suspended bonus was diffused in the plant. The freezing of the bonus occurred whilst the organisation was simultaneously increasing production and hiring, despite managerial claims of economic uncertainty. This apparent disjuncture was noticed on the shop-floor and articulated through representatives at the NER. At an NER meeting, a management presentation to representatives claimed that whilst the company was increasing production, it was equally experiencing increased costs, unfavourable exchange rate fluctuations and being squeezed for discounts by cashstrapped customers. Explaining the financial context through the NER was seen by senior management to displace inaccurate employee perceptions. Nonetheless, 
information collected from workers would suggest continued cynicism about the veracity of management's claims. Given that the NER dynamics were communicative, there appeared little scope for genuine mutual gains processes based around enduring consultative dialogue. Yet the CEO and HRM team complained that employees saw the forum as a 'dumping ground' for shop-floor grievances and articulated a desire that employees would contribute ideas to "add value" to the business, like increasing output or improving product quality. Indeed there is some support for managements' assessment from interviews with representatives, who articulate their role as mediums for airing constituent grievances which management could subsequently act upon.

A further barrier to embedding mutual gains were competitive pressures that impacted on the shopfloor. In the immediate aftermath of the 2008 recession, the industry in which the company operated suffered a 30 percent downturn, resulting in management seeking new ways of generating revenue streams. Such pressures resulted in the release of company products onto a market where the average price generated was lower with the result that less money was generated, whilst underlying costs remained the same. To lessen these pressures, standard production times were reviewed to get underlying costs down and efficiency rates increased. Changes occurred in internal quality standards with the introduction of barcode systems enabling full quality oversight and control throughout the manufacturing process. Such initiatives had ramifications for those at the point of production. As shop-floor employees put it: 
I always feel under pressure to get the work out as management want quality and quantity which is impossible as the targets are so high.

Production Employee

Horrible pressure, loads of stress, targets and targets only. It feels that management couldn't care less about their workforce or their views or opinions of the company just as long as their targets are being met.

Production Employee

The pressure to meet production and quality targets impacted on the NER, even from the point of being a grievance-raising vehicle. Employee representatives reported difficulties in securing 'points' from their constituents. Two representatives reported pressures from supervisors, themselves under pressure to ensure their work group met targets, to resume duties on return from the Forum. This limited opportunities to feedback to constituents. Individual representatives also personally opted to return to work perceiving that they had too much work to complete to ensure they hit their daily targets. Shop-floor employees commented on their dislike of being called to collective meetings with representatives, perceiving them as a distraction from their work. Despite the formal allocation of time for representatives to undertake their duties, this was not available in practice or utilised. Representatives reported 'rushing around' before meetings to gather points from employees, often leaving their workstations as near to the meeting time as possible to ensure workloads were not sacrificed. In any case, opportunities to develop the NER as a vehicle for mutual gains were inauspicious: there appeared to be a widely held view amongst employees that the Employee Forum was little else than a vehicle for downward 
communication and, crucially, ineffective for problem resolution. Employees claimed that whenever a representative was pushed for progress on a particular issue, like the frozen bonus, their response was repeatedly that the issue was under review and would be addressed in the near future. Such indeterminacy appears to have led to widespread employee cynicism and disengagement. By the conclusion of fieldwork, the NER, and the representatives, appeared to be displaced by what employees perceived to be a more effective problem-solving contact at the point of production: the immediate supervisor. Supervisors were perceived to be speedier, and potentially more effective, agents in resolving individual employee concerns.

At RetailCo, despite a structurally elaborate system of voice, there was limited evidence of effective mutual gains problem-solving. Where discerned it often appeared contingent on idiosyncratic management style or site-specific factors. Whilst it was difficult to find evidence of joint problem-solving at work in the Republic store, in the Northern Ireland site, occasional examples of collaborative actions were found. At store level, for a given year, sites are expected to secure at least 95 per cent profitability. If this is not reached, managers and employees do not receive their annual bonus. At the Northern Irish store, employees had raised a concern at the NER that more staff required training on electric pallet trucks as work groups were reliant on a handful of individuals for accessing stock in the store room. Store level HRM proceeded to review the percentage of staff trained at the site compared to other comparable outlets and found that the numbers trained compared favourably. This finding was then reported to employee representatives at a subsequent NER meeting along with the cost of additional training. The decision was left to the employee representatives as to whether they wished to pursue training, deducting 
the money from the store profit and loss account, which was made available to staff. After consultation with employee constituents, the request to pursue further training was dropped as employees feared that training costs would undermine store profitability targets and annual bonuses.

Aside from this and a small number of similar incidences, it was difficult to discern other examples of such behaviour. Similar to ManufactureCo, there was ambiguity about how management viewed the NER and the potential for mutual gain. Whilst there were senior management claims that the NER scheme aspired to information and consultation, this could also co-exist with a view that such bodies were primarily "information download". If gains were obtained, these mostly gravitated to management:

Does Bottom-Up improve the business? I don't think in its current format it truly does. If you look at improving the business as not having problems, then it does in some way do that by having it there. It prevents something else from being created that could hinder the business. But of its very nature, it is quite downloady, business-led and almost management having the responses in advance of what the questions are.

HRM Director, Republic of Ireland

In this regard, the NER (similar to ManufactureCo) reflects what Geary and Trif (2011) identify as 'constrained mutuality'. That is, the NER was largely viewed as being a form of problem-displacement rather than joint problem-solving and geared to isolating employee grievances within a managerially controlled format: 
There is an avenue there...a place for venting....if it wasn't there where would it go? Would it go to a Rights Commissioner [state arbitration]? Would it invite unions in because you didn't have a voice? So it's effective at that level that if you have got an issue: "have you spoken to your Bottom-Up Rep about it?" "Have a chat with them, stick it in the pot, let's manage it that way". It's easy to do that kind of stuff.

Store Manager, Republic of Ireland

That mutual gains characteristics were largely absent was further evidenced by store level manager complaints that employees simply used the forum 'negatively' to advance grievances on issues like vending machines, broken toilet seats and store level heating. According to one store level manager, Bottom-Up:

Should be a more positive forum and that's a challenge...it tends to bring the ideas from people that are not happy with things...It has got twisted in that it's all about negativity.

HR Director, Republic of Ireland

Again, similar to ManufactureCo, senior management did evince an aspiration that the forum might be a space whereby employees could contribute ideas on sales or customer service; for example, by taking 'ownership' of such issues like communicating back to staff various company rules on new uniforms or holiday entitlements. Similar to Manufacture Co., employees and NER reps regarded the forum however as a space for airing grievances. Yet even on this understanding, 
employees, and the majority of representatives interviewed, were sceptical of the NER's utility for resolving grievances. At a store studied in the Republic, employees continuously raised grievances regarding temperature levels inside the facility during the summer months. Employees complained to store management, raised the issue at Store Bottom-Up, then again the Regional Bottom-Up, up to Divisional level. Despite these repeated attempts, no resolution of the issue was undertaken by management. Consequently, one of the employees in the store reported the matter to the Health \& Safety Authority (HSA). The HSA investigated the complaint and found it to be valid, serving the company with an enforcement notice, which was subsequently complied with. A similar issue existed in a site studied in Northern Ireland, where employees continually complained about the cold on a shop-floor during the winter. Again in this case, employees reported that despite repeated airings at the store NER from 2008, management had not, by 2010 , yet acted on the grievance. As one employee observed:

You have an opportunity to voice an opinion, but whether any heed will be taken of that is another thing altogether.

Employee Representative, Northern Ireland

Again similar to ManufactureCo, the NER appeared to be displaced in any case by employees opting to raise grievances with their immediate line manager. Again, line management, and not the NER, were seen as offering a more effective and timely means for resolving grievances. 
Together, the three cases illustrate that the elements of power and autonomy offered to employee representatives in theory in the $I \& C$ regulations were not enabling of collaborative mutual gains joint problem-solving in practice. As such, the regulations had little impact in our cases in remedying the shortcomings of NER identified elsewhere.

\section{Discussion and Conclusion}

This paper reported on three cases where NERs had been devised under the influence of the I\&C regulations. The evidence found that the regulations merely prompted a reactive response (BritCo. and RetailCo.) or was a very minor reason behind tailoring the NER scheme (ManufactureCo.). Even in those cases where explicit initiatives were found, responses were of a 'tick-box' exercise. Aside from one or two instances, in all three cases there was little evidence of embedded or extended mutuality. In light of literature concerns, the issue is why the remoulding of structures away from a purely voluntarist format to a quasi-legal one, constructed under the shadow of the law, remained ineffective in delivering mutuality? With reference to the aforementioned constructs of power and autonomy, these crucial benchmarks remained unaffected because of the ample scope for employers to manoeuvre around the regulations. In a voluntarist context, even where initial impulses were propelled by legislative requirement, management were able to capture ensuing voice processes. This capacity is undoubtedly enhanced in nonunion environments where the balance of advantage is already tilted in managements' favour (Gollan, 2007). 
With reference to power, the scope and range of issues remained predominately under the control of management. In BritCo, the opportunities for mutual gains were perhaps most evident in the initial stages of the revamped NER, when issues of some import were considered, like redundancy. However, it is difficult to ascribe this as being assisted by the I\&C regulations in any meaningful sense. Whilst conducted through a structure that could trace its legacy to the regulation's influence, the dynamics of this case were defined more by the proximity of the union recognition campaign than any legislative promptings for 'an exchange of views or establishment of dialogue'. The latent power relied upon by workers could perhaps be best conceptualised as relying upon union, rather than legislative, power bases. As this latent power base seemed to lose momentum and dwindle, the range of issues were replaced by relatively secondary matters of an incidental and operational nature: a very weak form of mutual gains attainment. Management at BritCo demonstrated a partial commitment to mutual gains problem-solving in terms of the scope of issues, but this was only insofar as it did not intrude or dilute the management prerogative. In ManufactureCo and RetailCo the failings of these NER regimes rested on management being inclined to information but not consultation. At ManufactureCo, management sent mixed messages on the scope and range of the forum: whilst using the NER for downward communication, management also claimed to secure employee input into the 'strategic' direction of the company. In reality, this translated into a desire for workers to contribute improvements at the operational level, which in any case was undermined by an environment punctuated by a pervasive, and resented, target-setting. These difficulties relate to the conceptualisation of autonomy. Whatever autonomy is promised in the formal properties of I\&C influenced forums, in practice, managerially initiated forums of this kind may suffer 
from a lack of institutional distance and thus undermine the realisation of genuine autonomy.

The limited nature of the NERs in both ManufactureCo and RetailCo to deliver substantial gains for employees notably led to its displacement by alternative avenues like line management, a feature not hitherto examined in the NER literature. Of course the limitations of the findings must be acknowledged here as a potential source of bias: two of the three cases had elements, to varying degrees, of unionavoidance inclinations in informing the NERs. In BritCo and ManufactureCo the forums were revitalised when union voice became a spectre on the horizon. Even in RetailCo, where the NER, with all its limitations, had been institutionally sustained over a considerable period of time, a potential union threat remained something of an underlying motivator. It must be stressed then that this particular case of unitary anti-unionism was hardly propitious for the emergence of non-union partnership: the potential for mutual gains might have been different in a more receptive managerial climate of sophisticated human relations (Kessler and Purcell, 2003).

However, explanations for the absence of mutual gains, certainly at ManufactureCo. and RetailCo, are not wholly attributable to the actions of management, but are also partly connected to the nature of employee agency. In both cases, employees saw the NER as problem-solving only in so far as grievances would be raised and then passively left to management to resolve. When this proved ineffective, line management were turned to. As such it is questionable whether employees sought to be self-governing autonomous actors with influence over the representative structure, process or agenda or whether they opt for a more 'servicing' arrangement. 
The capabilities needed by worker representatives to engage in meaningful problemsolving, such as a readiness to actively participate in the democratic engagement implied by a mutual gains process, were not evident. As is well established in the literatures on industrial democracy, education and training of workers and elected representatives is crucial to secure the effective operationalisation of participation arrangements (Varman and Chakrabarti, 2004). This is not altogether surprising given the non-union context of both companies and the fact that workers and their representatives had no knowledge or experience of the legislative requirements of the I\&C Regulations. Even where there was robust union involvement in the background, as in BritCo, the union was disinterested in utilising the potentials afforded by I\&C sponsored NERs. Employees were not conscious, and in some instances did not seek or know how to seek, the latent power resources inherent in the regulations. Thus this power base of independent, statutory support went unutilised in the absence of knowledge and a 'willingness to act' (Butler, 2005: 276). Ultimately mutual gains may be more enduring in a unionised sector where in the event that management fail to live up to their side of the bargain, employees can autonomously mobilise latent power resources of union organisation to become a more awkward partner and thus coax management back to the problem-solving table (Martin, 1992). Whilst non-unionised workers can and do challenge employers, they do have fewer avenues of persuasion when management shows itself to be a less than willing participant.

In light of the cases here, there are some policy implications relating to the limited functionality of NERs for delivering mutual gains outcomes in voluntarist contexts. For an NER to be imbued with greater mutual gains capabilities, revision of the UK 
and Irish regulations transposing the I\&C Directive is one measure that would need to be considered. The minimalist transposition of the Regulations in these two jurisdictions means current procedures are deficient in enabling employees in nonunion enterprises to exercise sufficient power and autonomy over I\&C dynamics. Employers also have substantial freedom to customise shallow communicative operational forms of NER voice in preference to more robust consultative arrangements that integrate employee representatives into problem-solving dynamics for mutual gains purposes. Of course one caveat here is that this study focuses on instances where pre-existing agreements have been adopted. Structures self-consciously 'triggered' by employees for example, might be imbued with greater degrees of power and autonomy than those cases where pre-existing agreements are exclusively managerially-crafted. This suggests that future research on the regulations look at those instances where employees have initiated the regulations. In any case, the capacity of management to craft an arrangement is assisted by the current design of the regulations in both jurisdictions. Accordingly, such flexibility offers those employers, who might wish to do so, the opportunity to construct I\&C bodies that fall far short of the mutual gains espoused in the original Directive. 


\section{Footnote}

[1] The ICE 'standard rules' specify that information and consultation must be provided on information pertaining to the economic situation of the organisation; information and consultation on the structure and probable development of employment (including any threats to employment); information and consultation, with a view to reaching agreement, on decisions likely to lead to changes in work organisation or contractual relations. ICE regulations also allow employers to establish a 'pre-existing agreement' i.e. alternative voluntary I\&C arrangements that may differ from the standard rules and established prior to an employee request.

\section{References}

Ackers, P., Marchington, M., Wilkinson, A. and Dundon, T. (2004), 'Partnership and Voice, with or without Trade Unions: Changing UK management approaches to organisational participation', in M. Stuart, and M. Martinez Lucio (eds.), Partnership and Modernisation in Employment Relations, London, Routledge.

Bacon, N. and Blyton, P. (2007), 'Conflict for Mutual Gains', Journal of Management Studies, 44(5): 814-834. 
Badigannavar, V. and Kelly, J. (2005) 'Labour-management Partnership in the Nonunion Retail Sector', International Journal of Human Resource Management 16(8): 1529-44.

Butler, P. (2005) 'Non-union employee representation: exploring the efficacy of the voice process', Employee Relations, 27(3): 272-288.

Danford A., Richardson, M., Stewart, P., Tailby, S. and Upchurch, M. (2004) 'High

Performance Work Systems and Workplace Partnership: A Case Study of Aerospace Workers', New Technology, Work and Employment 19(1): 14-29.

Dietz, G., Cullen, J. and Coad, A. (2005) 'Can there be Non-union Forms of Workplace Partnership?', Employee Relations, 27(3): 289-306.

Dobbins, T. and Gunnigle, P. (2009) 'Can voluntary workplace partnership deliver sustainable gains?', British Journal of Industrial Relations, 47(3): 546-570.

Dundon, T., Curran, D., Maloney, M. and Ryan, P. (2006), 'Conceptualising the dynamics of employee voice: evidence from the Republic of Ireland', Industrial Relations Journal, 37(5):492-512.

Freeman, R.B. and Medoff, J.L. (1984) What Do Unions Do? New York: Basic Books.

Geary, J. and Trif, A. (2011) 'Workplace partnership and the balance of advantage: a critical case analysis', British Journal of Industrial Relations, 49(2): 44-69.

Gollan, P.J. (2007) Employee Representation in Non-Union Firms, London: Sage.

Gollan, P.J. (2010) 'Employer strategies towards non-union collective voice', in A. Wilkinson, P.J. Gollan, M. Marchington and D. Lewin (eds.), The Oxford Handbook of Participation in Organizations, Oxford: Oxford University Press. 
Guest, D., Brown, W., Peccei, R. and Huxley, K. (2008) 'Does partnership at work increase trust? An analysis based on the 2004 Workplace Employment Relations Survey', Industrial Relations Journal, 39(2): 124-152.

Hall, M. (2005) 'Assessing the Information and Consultation of Employees Regulations', Industrial Law Journal, 34(2): 103-126.

Hall, M., Hutchinson, S., Purcell, J., Terry, M. and Parker, J. (2011) 'Promoting effective consultation? Assessing the impact of the I\&C Regulations', British Journal of Industrial Relations, ON-LINE EARLY: 1-28.

Johnstone, S., Ackers, P. and Wilkinson, A. (2010) 'Better than Nothing? Is Nonunion Partnership a Contradiction in Terms?', Journal of Industrial Relations, 52(2): 151-168.

Kaufman, B. and Taras, D. (2000) Non-Union Employee Representation: History, Contemporary Practice and Policy, Armonk, NY: M.E. Sharpe.

Kelly, J. (2004) 'Social partnership agreements in Britain: labor cooperation and compliance', Industrial Relations, 43(1): 267-292.

Kessler, I. and Purcell, J. (2003) 'Individualism and collectivism in industrial relations', in P. Edwards (ed.), Industrial Relations, Oxford: Blackwell.

Kim, D.O. and Kim, H.K. (2004) 'A comparison of the effectiveness of unions and non-union works councils in Korea: can non-union employee representative substitute for trade unionism', International Journal of Human Resource Management, 15(6): 1063-1093.

Knell, J. (1999) Partnership at Work? Employment Relations Research Series. London: DTI.

Kochan, T.A. (2008) 'Introduction to a symposium on the Kaiser Permanente labour management partnership', Industrial Relations, 47(1): 1-9. 
Kochan, T.A. and Osterman, P. (1994) The Mutual Gains Enterprise, Harvard, MA: Harvard Business School Press.

Koukiadaki, A. (2010) 'The establishment and operation of information and consultation of employees' arrangements in a capability-based framework', Economic and Industrial Democracy, 31(3): 365-388.

Lewin, D. (2010) 'Employee voice and mutual gains', in A. Wilkinson, P.J. Gollan, M. Marchington and D. Lewin (eds.), The Oxford Handbook of Participation in Organizations, Oxford: Oxford University Press.

Martin, R. (1992) Bargaining Power, Oxford: Clarendon Press.

McKersie, R.B., Sharpe, T., Kochan, T.A., Eaton, A.E., Strauss, G. and Morgenstern, M. (2008) 'Bargaining theory meets interest-based negotiations', Industrial Relations, 47(1): 66-96.

Metcalf, D. (1989) 'Water notes dry up: the impact of the Donovan reform proposals and Thatcherism at work on labour productivity in British manufacturing industry', British Journal of Industrial Relations, 27(1): 1-32.

Poole, M. (1975) Workers' Participation in Industry, London: Routledge and Kegan Paul.

Sisson K (2002) The Information and Consultation Directive: Unnecessary 'Regulation' or an Opportunity to Promote 'Partnership'? Warwick Papers in Industrial Relations, No. 67. Coventry: Industrial Relations Research Unit, University of Warwick.

Stuart, M. and Martinez Lucio, M. (2005) 'Partnership and modernisation in employment relations: an introduction', in M. Stuart and M. Martinez Lucio (eds.), Partnership and Modernisation in Employment Relations, Basingstoke: Palgrave Macmillan. 
Taylor, P., Baldry, C., Danford, A., and Stewart, P. (2009) 'An umbrella full of holes?: corporate restructuring, redundancy and the effectiveness of ICE Regulations', Relations Industrielles, 64(1): 27-49.

Teague, P. and Hann, D. (2010) 'Problems with partnership at work: lessons from an Irish case study', Human Resource Management Journal, 20(1): 100-114.

Upchurch, M., Danford, A., Tailby, S. and Richardson, M. (2008) The Realities of Partnership at Work, Basingstoke: Palgrave Macmillan.

Varman, R. and Chakrabarti, M. (2004) 'Contradictions of Democracy in a Workers' Cooperative', Organization Studies, 25(2): 183-208.

Walton, R.E. and McKersie, R.B. (1965) A Behavioral Theory of Labor Negotiations, New York: McGraw-Hill.

Wilkinson, A. and Gollan, P.J. (2007) 'The EU Information and Consultation Directive and the future of employee consultation in the UK', International Journal of Human Resource Management, 18(7): 1145-1158.

\section{Legislation Cited}

Directive 2002/14/EC of the European Parliament and of the Council of 11 March 2002 establishing a general framework for informing and consulting employees in 
the European Community', Official Journal of the European Communities, 23 March (80): 29-33.

\section{Appendix}

Table 1: Case studies' details

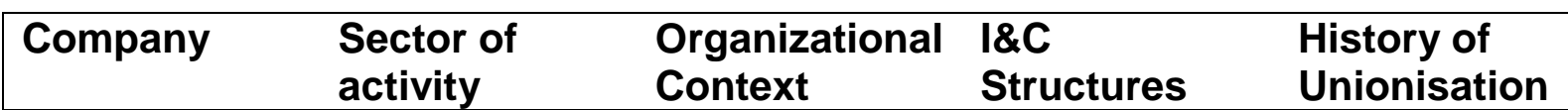




\begin{tabular}{|c|c|c|c|c|}
\hline Brit Co. & Services & $\begin{array}{l}\text { Evolved from } \\
\text { acquisition of } \\
\text { company in the } \\
\text { Republic in } \\
2000 \text { and } \\
\text { subsequent } \\
\text { merger with } \\
\text { Northern } \\
\text { Ireland into one } \\
\text { all-island entity } \\
\text { in } 2003 \text {. } \\
\text { Employs } 2000 \\
\text { in Republic } \\
\text { where study } \\
\text { set in variety of } \\
\text { engineering, } \\
\text { support staff } \\
\text { and sales } \\
\text { roles. }\end{array}$ & $\begin{array}{l}\text { I\&C Forum set } \\
\text { up in } 2005 \text { as } \\
\text { a pre-existing } \\
\text { agreement in } \\
\text { response to } \\
\text { I\&C } \\
\text { Regulations }\end{array}$ & $\begin{array}{l}\text { Non-union in } \\
\text { Republic of } \\
\text { Ireland, } \\
\text { although union } \\
\text { recognition } \\
\text { campaign } \\
\text { initiated in } \\
2007 \text { which } \\
\text { claimed to } \\
\text { have } 30 \% \text { of } \\
\text { workforce } \\
\text { support; } \\
\text { resisted by } \\
\text { management }\end{array}$ \\
\hline $\begin{array}{l}\text { Manufacture } \\
\text { Co }\end{array}$ & $\begin{array}{l}\text { Manufacture of } \\
\text { window blinds }\end{array}$ & $\begin{array}{l}\text { Family-owned } \\
\text { firm based in } \\
\text { Northern } \\
\text { Ireland; } \\
\text { experienced } \\
\text { rapid growth in } \\
\text { size during } \\
2000 \text { s. } \\
\text { Employs } 300 \\
\text { staff } \\
\text { predominately } \\
\text { involved in } \\
\text { various stage } \\
\text { of manufacture }\end{array}$ & $\begin{array}{l}\text { Employee } \\
\text { Forum set up } \\
\text { in } 2005 \text { as a } \\
\text { pre-existing } \\
\text { agreement in } \\
\text { response to } \\
\text { I\&C } \\
\text { Regulations } \\
\text { and Investors } \\
\text { in People (IiP) } \\
\text { advice }\end{array}$ & $\begin{array}{l}\text { Non-union } \\
\text { company; } \\
\text { union } \\
\text { recognition } \\
\text { campaign } \\
\text { initiated in - } \\
\text { but failed to } \\
\text { meet criteria; } \\
\text { management } \\
\text { hostile to idea } \\
\text { of union } \\
\text { involvement }\end{array}$ \\
\hline Retail Co. & $\begin{array}{l}\text { Home } \\
\text { improvement } \\
\text { and DIY retail }\end{array}$ & $\begin{array}{l}\text { British-owned } \\
\text { multinational; } \\
19 \text { outlets } \\
\text { across } \\
\text { Northern } \\
\text { Ireland } \\
\text { Republic; } \\
\text { employing } \\
1500 \\
\text { predominately } \\
\text { in retail-sales } \\
\text { roles. }\end{array}$ & $\begin{array}{l}\text { Internal array } \\
\text { of informal and } \\
\text { formal voice } \\
\text { mechanisms } \\
\text { used } \\
\text { historically. } \\
\text { NER forum } \\
\text { reconfigured in } \\
\text { early } 2000 \text { s to } \\
\text { provide for } \\
\text { formal, elected } \\
\text { representation }\end{array}$ & Non-union \\
\hline
\end{tabular}

Table 2: The narrowing of mutual gains collaboration at BritCo 


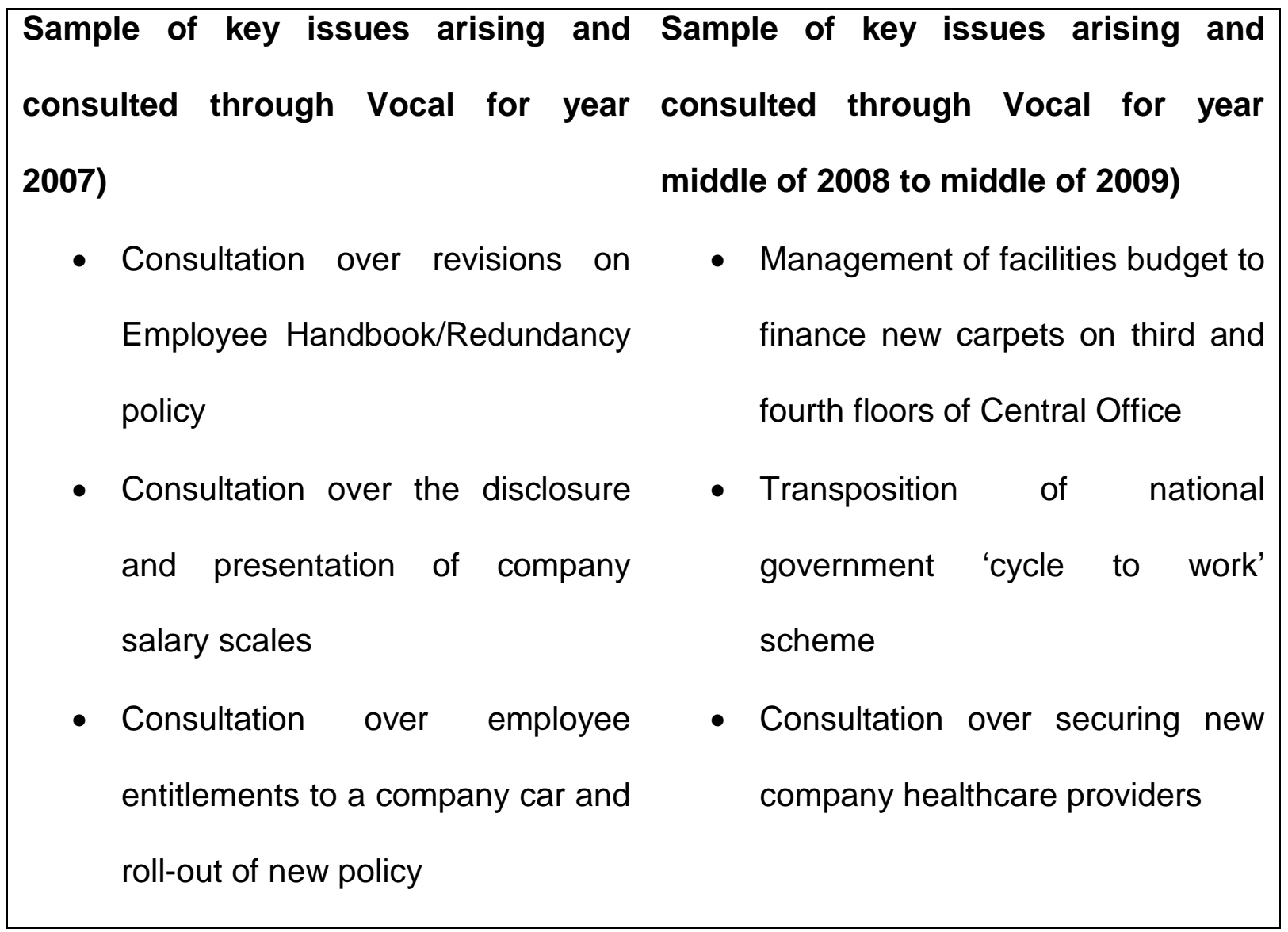

